\title{
48. CORRELATION OF EOCENE-OLIGOCENE CALCAREOUS NANNOFOSSIL ASSEMBLAGES FROM PISTON CORES TAKEN NEAR DEEP SEA DRILLING SITES 511 AND 512, SOUTHWEST ATLANTIC OCEAN ${ }^{1}$
}

\author{
Sherwood W. Wise, Jr., Department of Geology, Florida State University, Tallahassee, Florida \\ and \\ Elena L. Mostajo, Museo Argentino de Ciencias Naturales “B. Rivadavia,” 1405 Buenos Aires, Argentina
}

\begin{abstract}
Calcareous nannofossil assemblages recovered in four Islas Orcadas piston cores along the northern margin of the Maurice Ewing Bank on the eastern Falkland Plateau are correlated with lower Oligocene and middle Eocene sections at Deep Sea Drilling Project Sites 511 and 512, respectively. Results indicate that the Paleogene section near the piston core stations is generally more calcareous and complete than at the Leg 71 drill sites and could provide a valuable highlatitude biostratigraphic reference locality if drilled at some future date.
\end{abstract}

\section{INTRODUCTION}

During April 1978, a series of Islas Orcadas Cruise 16 piston cores were taken along the heavily eroded northern margin of the Maurice Ewing Bank on the eastern Falkland (Malvinas) Plateau (Wise et al., 1978) in order to trace the outcrop belt of older (pre-Pliocene) sediments thought to be exposed there (Ciesielski and Wise, 1977). Basal sediments of the 13 piston cores taken along the northern margin range from Paleocene to Miocene in age (Jones et al., 1979) and suggest the presence of a high-latitude Paleocene to Oligocene section of mixed calcareous-siliceous oozes over 200 meters thick.

It was originally hoped that DSDP Site 512 could be located at a shallow depth (about $1500 \mathrm{~m}$ ) somewhere along the steeply sloping northern margin of the Maurice Ewing Bank so that the exposed Oligocene-Paleocene section could be sampled by hydraulic piston coring. Unfortunately, there were no seismic profiles adequate to evaluate sufficiently potential hydrocarbon hazards, and the site was eventually relocated some distance to the southeast in about 1850 meters of water, where the older sediment section is more abbreviated.

Nevertheless, the Islas Orcadas piston cores near the initially proposed drill site do provide a valuable insight into the nature of the sediments higher up on the Maurice Ewing Bank. Among those cores are four which are closely correlative in age with the materials obtained at the Leg 71 drill sites (see Fig. 1). The objective of this paper is to describe and correlate the coccolith assemblages from those piston cores with the assemblages described from the Leg 71 drill cores (Wise, this volume). Gombos (1982) recently described three new genera of ebridians from these same cores and provided general age determinations based on diatoms.

\footnotetext{
${ }^{1}$ Ludwig, W. J., Krasheninnikov, V. A., et al., Init. Repts. DSDP, 71: Washington (U.S. Govt. Printing Office).
}

\section{RESULTS}

Figure 2 shows the lithologies of the four piston cores taken along the northern Maurice Ewing Bank that can be closely correlated with the middle Eocenè and lower Oligocene sections cored at DSDP Sites 512 and 511, respectively (lithologies condensed from Kaharoeddin et al., 1982). The calcareous nannofossil stratigraphies are given in Tables 1 and 2. A list of species encountered is given in the Appendix.

It should be borne in mind that isolated piston cores must necessarily be examined out of the context of the sections from which they were retrieved. The short intervals recovered in older piston cores (usually no more than a meter or two in length) constitute only a small fraction of the total section that would be obtained in the same locality by drill cores, and variations in species abundances may lead to false conclusions about the stratigraphies or the dates of the isolated piston core sections. Nevertheless, the general age assignments given these cores on the basis of coccoliths agree with the middle Eocene and early Oligocene ages suggested by Gombos (1982), who examined the diatoms.

Islas Orcadas (IO) Core 16-43 contains abundant Chiasmolithus solitus and Reticulofenestra umbilica, which together define the Discoaster bifax Subzone of Bukry (1973a). Rare D. bifax were noted at the base of the core, and forms here attributed to $R$. bisecta bisecta are few to abundant throughout. Individuals of the latter species are small, about 9 to $10 \mu \mathrm{m}$ long (about the size of the holotype of the species) and exhibit a low-order yellow interference color in crossed polarized light. Such forms were encountered only in Cores 8 and 9 at DSDP Site 512, where they were lumped under the name Reticulofenestra sp. cf. $R$. hesslandii (Wise, this volume, Table 5). Some other forms lower down in the section at Site 512 were included under that taxonomic heading, but these are smaller; they do not exhibit a yellow interference color, and are not the same species as those in Islas Orcadas Core 16-43. 


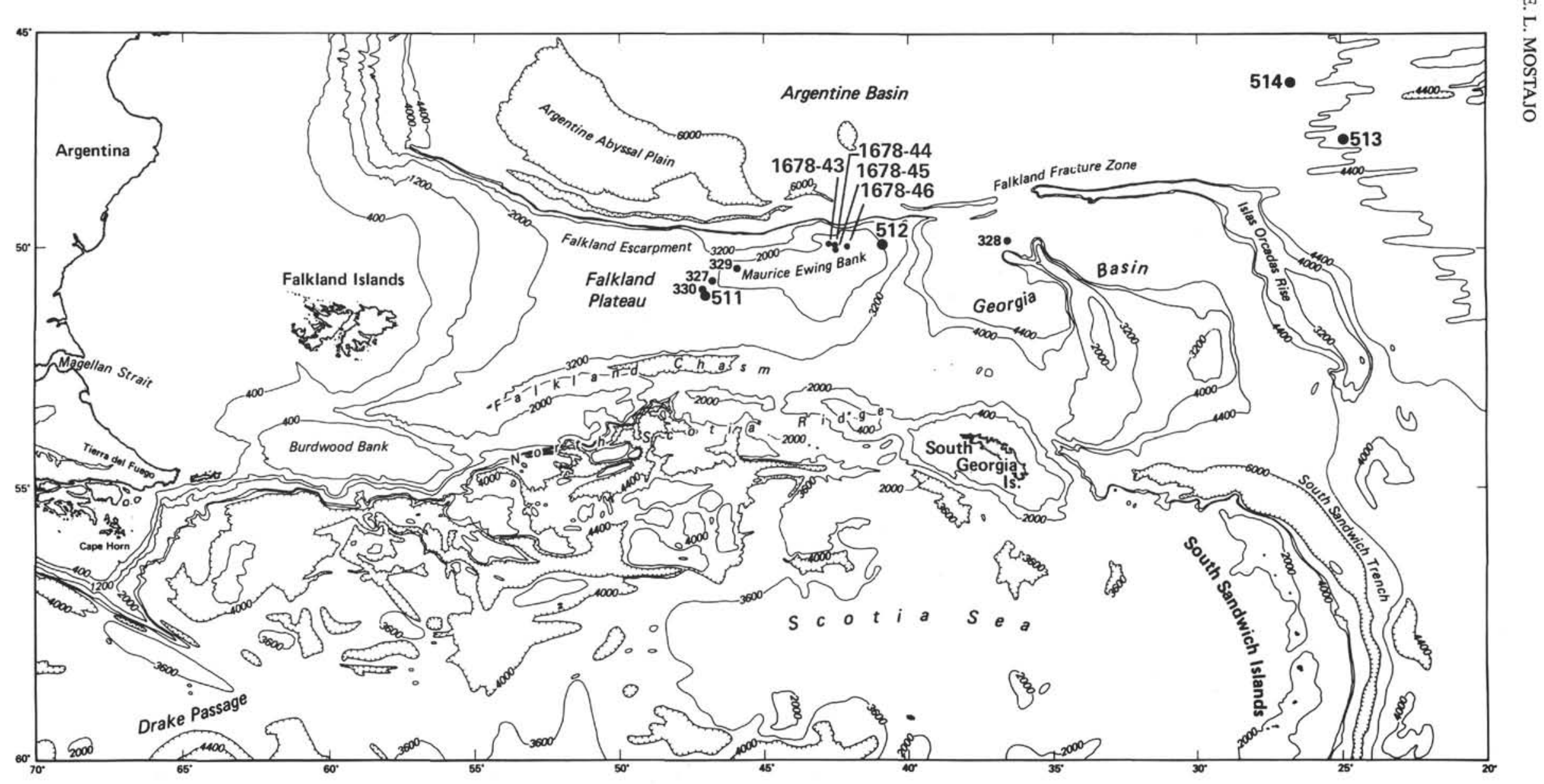

Figure 1. Locations of DSDP Sites 511 and 512 and of Islas Orcadas piston cores used in this study. 


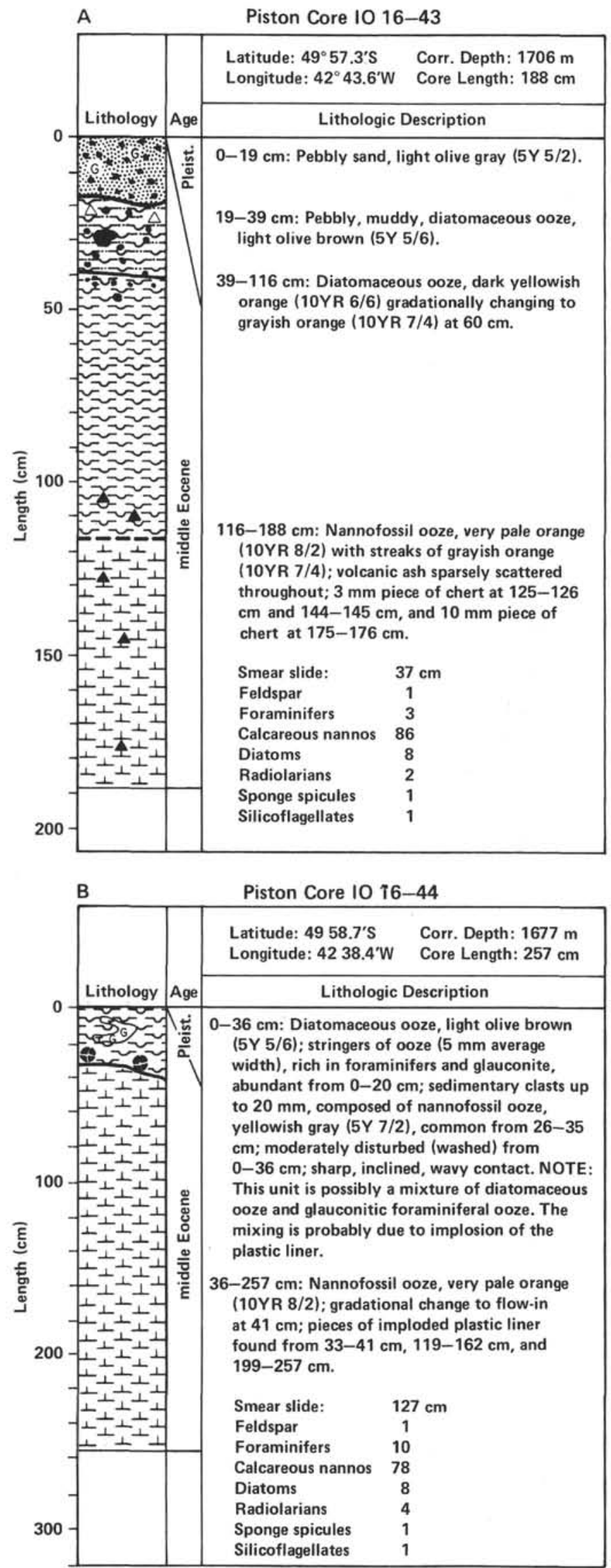

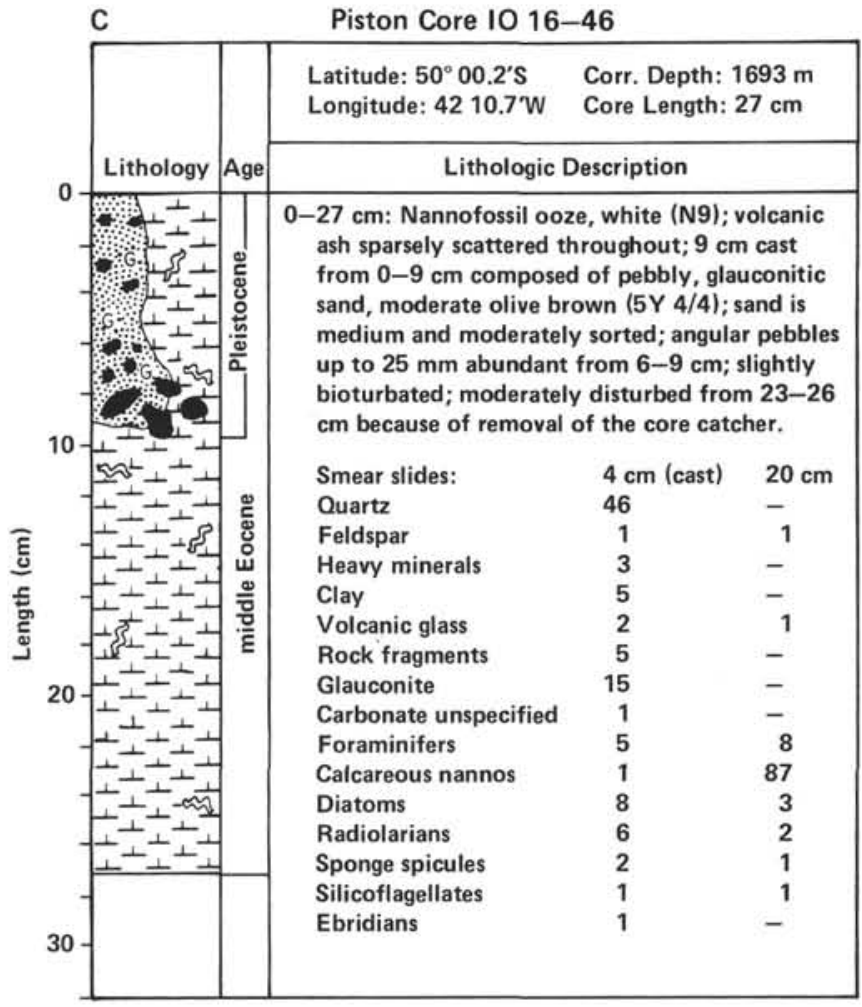

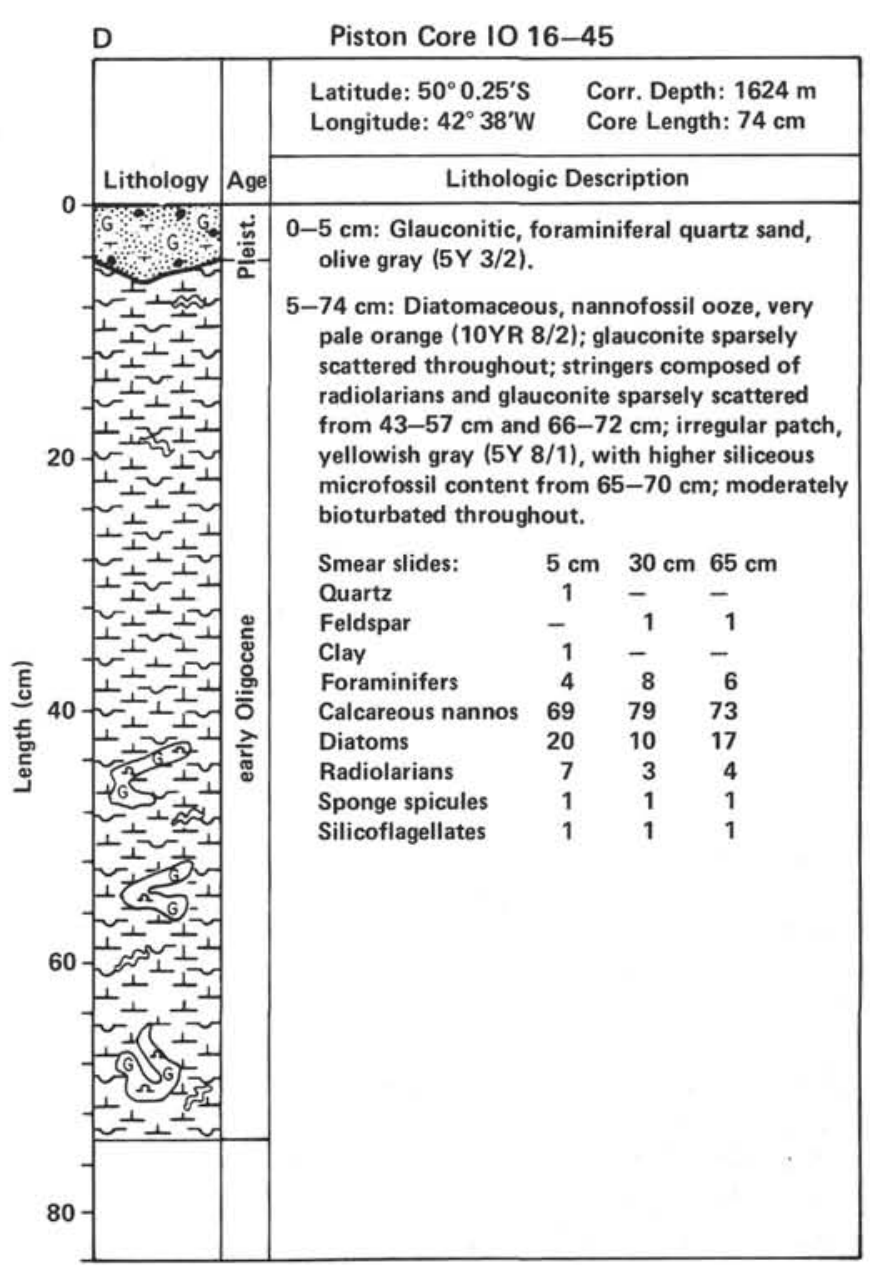

Figure 2. Lithologies of Islas Orcadas (IO) Cruise 16 piston cores 16-43, 16-44, 16-46, and 16-45 (from Kaharoeddin et al., 1982). 
Table 1. Distribution of middle Eocene calcareous nannofossils in Islas Orcadas (IO) Cores 16-43, 16-44, and 16-46.

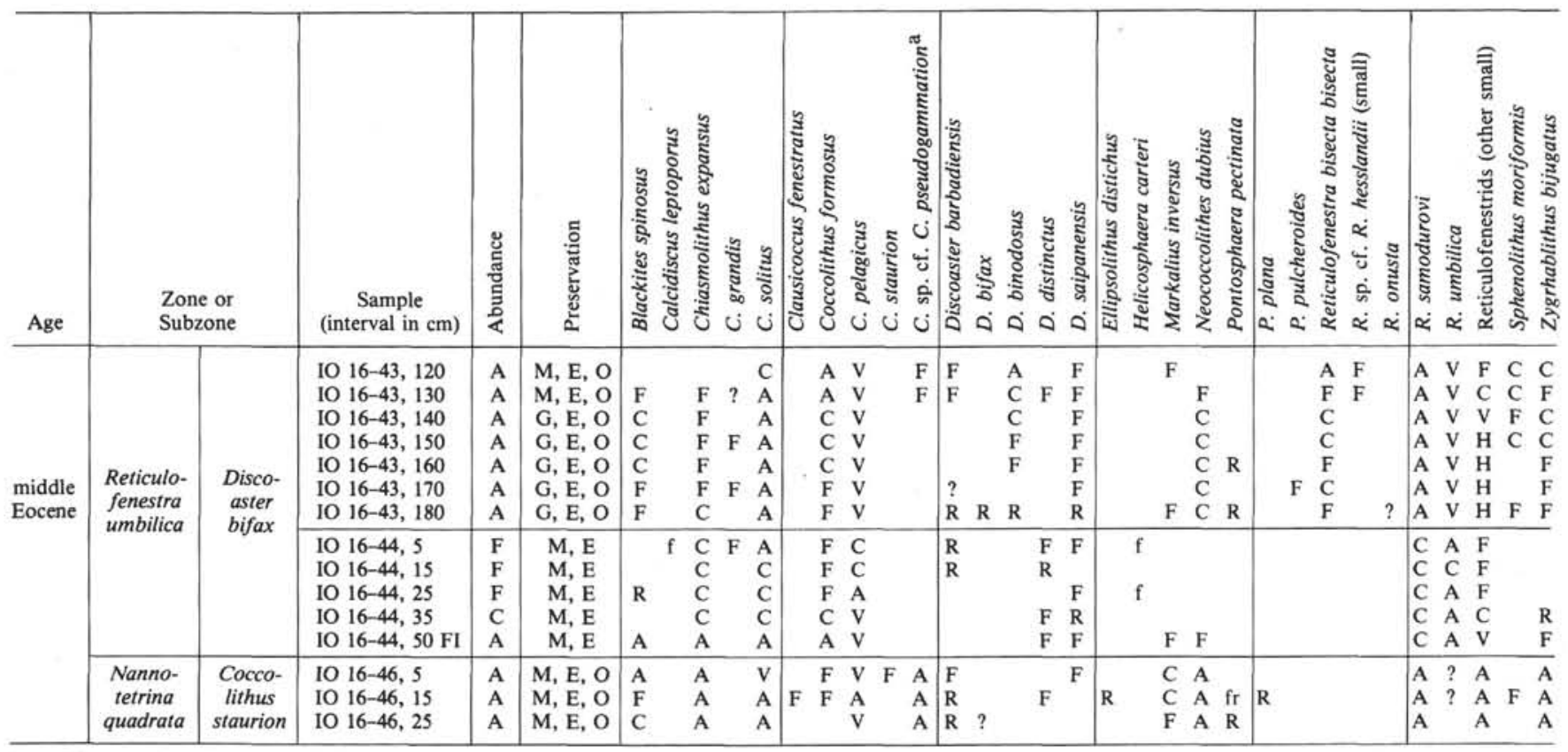

Note: $\mathrm{V}=$ very abundant; $\mathrm{H}=$ highly abundant; $\mathrm{A}=$ abundant $\mathrm{C}=$ common; $\mathrm{F}=$ few $; \mathrm{R}=$ rare; $\mathrm{fr}=$ fragment $\mathrm{P}=$ poor $; \mathrm{M}=$ moderate; $\mathrm{G}=\mathrm{good} ; \mathrm{E}=\mathrm{etched} ; \mathrm{O}=$ overgrown; $\mathbf{F I}=$ flow-in. Abundances in lowercase denote reworked or contaminant specimens.

a Cyclicargolithus sp.

Table 2. Distribution of early Oligocene calcareous nannofossils in Islas Orcadas (IO) Core 16-45.

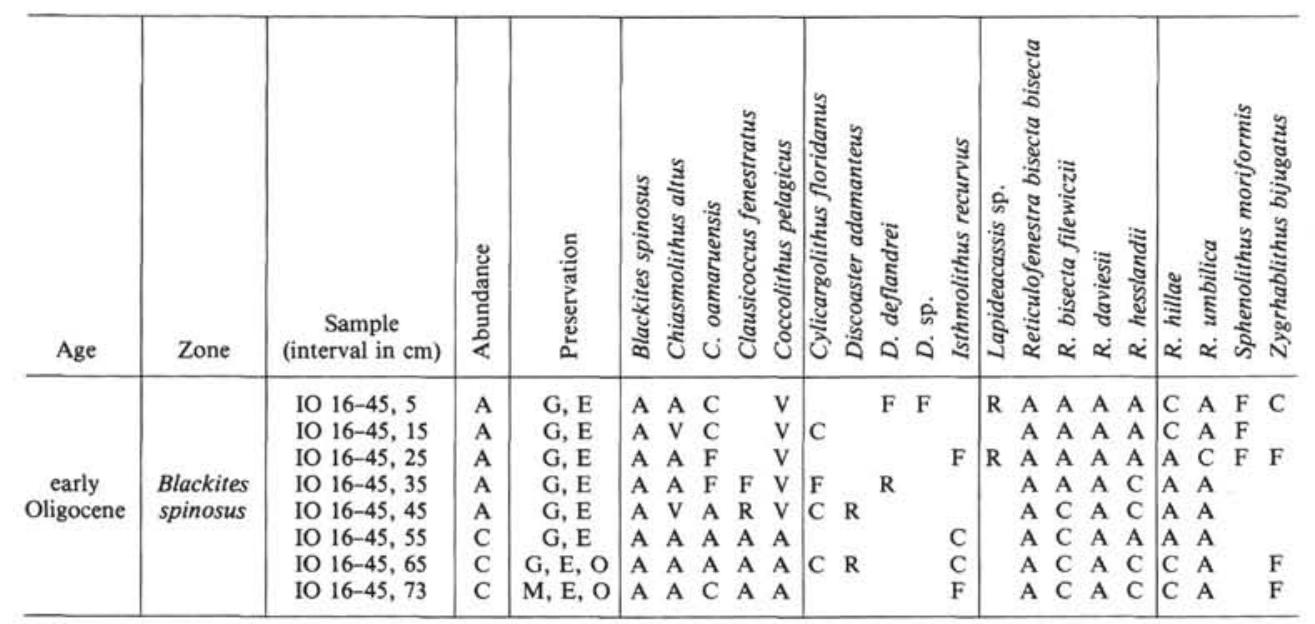

Note: $\mathrm{V}=$ very abundant; $\mathrm{A}=$ abundant $\mathrm{C}=$ common; $\mathrm{F}=$ few; $\mathrm{R}=\operatorname{rare} ; \mathrm{P}=$ poor; $\mathrm{M}=$ moderate $\mathrm{G}=$ good; $\mathrm{E}=$ etched; $\mathrm{O}=$ overgrown.

Bukry (1973a) indicates that $R$. bisecta bisecta makes its first appearance somewhere within the $D$. bifax Subzone. On the Falkland Plateau this appears to be the case with the species first appearing in the upper portion of the section at Site 512. It is not present above Core $512-8$, however, so its occurrence here may be sporadic in the lower part of its range. Its occurrence in Core IO $16-43$ is quite consistent, perhaps indicating that this core represents a stratum slightly younger than the section at Site 512 .

Core IO 16-44 is rather badly disturbed. Pleistocene glacial marine sediments in the top $40 \mathrm{~cm}$ are contaminated with middle Eocene coccoliths from the nannofossil ooze below because the plastic core liner im- ploded during core retrieval. Most of the nannofossil ooze contained in the remainder of the core is flow-in material which was drawn into the liner during core retrieval. Pleistocene coccoliths are represented by a few Calcidiscus leptoporus and Helicosphaera carteri in the top $35 \mathrm{~cm}$ of the core. Middle Eocene coccoliths include common to abundant Chiasmolithus solitus and R. umbilica but no $R$. bisecta. The absence of the latter could mean that the core sampled a lower stratigraphic level than that of Core IO 16-43. The evidence for this could be considered ambiguous, however, since $R$. bisecta is not consistently present in the upper part of the section at Site 512. No Sphenolithus furcatolithoides or S. radians were noted. This core, therefore, probably repre- 
sents a stratum lying somewhere above Section 512-19-1 and below Core 512-9.

In Core IO $16-46, C$. solitus is abundant, but no confirmed specimens of $R$. umbilica have been found. Instead, the assemblage contains abundant $R$. samoduro$v i$, which is similar to $R$. umbilica in appearance but is smaller. Bukry (1973a) considers $R$. samodurovi to be the progenitor of the larger $R$. umbilica, but does not specify what size difference he uses to distinguish the two. We attribute all forms larger than $14 \mu \mathrm{m}$ to $R$. umbilica. In Core IO 16-46, there are rare fragments of forms which must have approached $14 \mu \mathrm{m}$ in length, but no confirmed examples of $R$. umbilica were found. Since $R$. umbilica was consistently present through the section at Site 512, it would seem that Core IO 16-46 should probably be assigned to Bukry's (1973a) middle Eocene Coccolithus staurion Subzone. One specimen of C. staurion was noted in Sample 16-46, $5 \mathrm{~cm}$ (Table 1; Fig. 3). This species can also occur, however, in the $D$. bifax Subzone (Bukry, 1973a). Nannotetrina quadrata was not observed.

Core IO $16-45$ is dated as early Oligocene by the presence of Clausicoccus fenestratus and Isthmolithus recurvus in the absence of $D$. saipanensis and $R$. oamaruensis. In this respect, the core is equivalent to the Blackites spinosus Zone cored in a long sequence at DSDP Site 511. A single specimen of $D$. saipanensis was noted in an intermediate sample taken at $40 \mathrm{~cm}$ in Core IO 1645 (not shown in Table 2). This specimen, however, is apparently reworked, Gombos (1982, text-fig. 1) also suspected reworking at this interval. Neither $C$. fenestratus nor $I$. recurvus occur in the topmost $15 \mathrm{~cm}$ of the core. Because of the high sedimentation rate in this area, it is doubtful, however, that the upper boundary of the $B$. spinosus Zone is actually present in this core, although that remains a possibility. Strong fluctuations in the abundances of $C$. fenestratus were noted in the equivalent section at DSDP Site 511 (Wise, this volume, Table 1A), and this fact may account for its apparent absence at the top of Core 16-45. Scanning electron micrographs revealed exceptionally clear ultrastructural details for some of the Oligocene coccoliths of Core IO 16-
45. The Isthmolithus recurvus in Plate 1, Figures 1-3 are composed of a paper-thin wall constructed of narrow vertical laths. In one specimen (Plate 1, Figs. 1 and 2), the wall is folded into a small loop at one end (right side of specimen) and then overlapped along an oblique suture just beyond that point. This wall construction is markedly different from that of Neococcolithes dubius (Plate 4, Fig. 9) which has a wall composed of robust, strongly inclined elements (a characteristic eiffellithalid rim). There seems to be no reason to suppose that there is some sort of evolutionary link (or intermediate connecting form) between these two taxa as has sometimes been suggested in the literature.

\section{DISCUSSION}

Correlation of middle Eocene piston and drill cores from the Maurice Ewing Bank suggest that the piston cores represent fragments of a broader stratigraphic interval than that sampled at Site 512. Islas Orcadas Piston Cores 16-43 and 16-46 may represent, respectively, strata slightly younger and slightly older than the section at Site 512. On the basis of coccoliths the correct sequence of cores from youngest to oldest, is IO 16-43, 16-44, and 16-46. A. M. Gombos (pers. comm., 1982) reports that this sequence is in accord with his diatom data when measured against the diatom stratigraphy of Site 512 (Gombos, this volume).

Based on these data, the following sequence of calcareous nannofossil datums within or bounding the Discoaster bifax Subzone of the Reticulofenestra umbilica Zone can be suggested for the area of the Falkland Plateau (they are listed in descending stratigraphic order): LAD, Chiasmolithus solitus; FAD, Reticulofenestra bisecta bisecta; LAD, Sphenolithus furcatolithoides; FAD, $R$. umbilica. Since the entire $D$. bifax Subzone was not drilled or cored at any one locality, we cannot fully ascertain the reliability of these datums in this region. Further drilling would be required. Nor can we ascertain the duration of time encompassed by the $D$. bifax Subzone in this region. On the basis of Bukry's (1973b) calculations, the subzone spans only about $1 \mathrm{~m}$.y. If that is correct, then the sedimentation rate at Site 511 during that

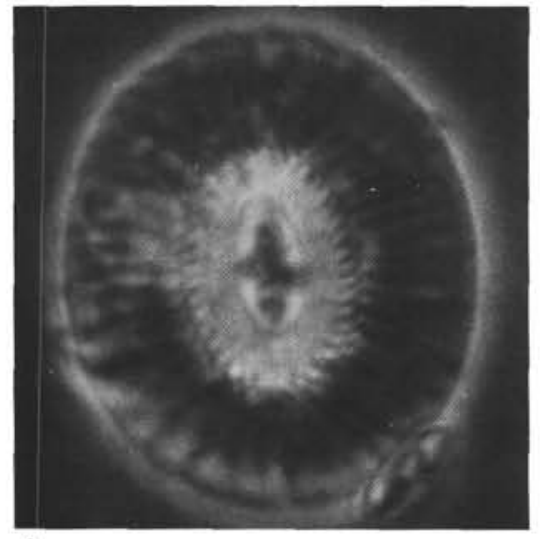

A

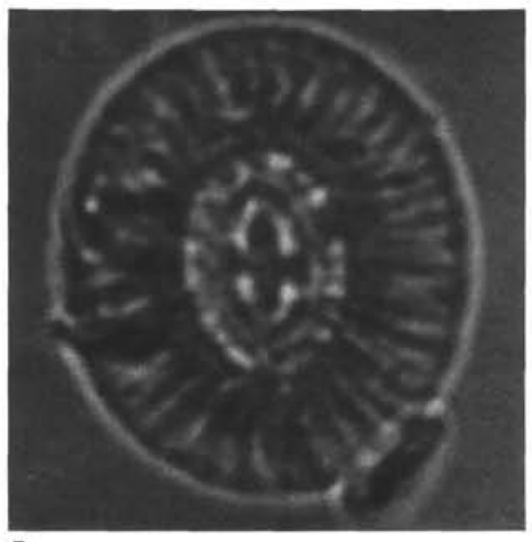

B

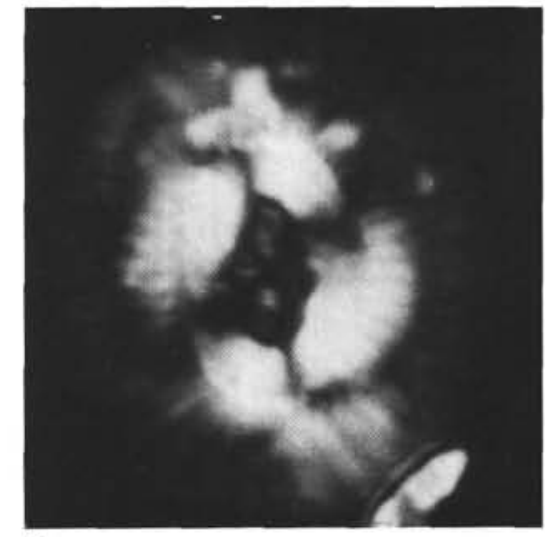

C

Figure 3. Coccolithus staurion Bramlette and Sullivan; Islas Orcadas Sample 16-46, $5 \mathrm{~cm}, \times 3200$. A, phase contrast light; B, transmitted light; C, cross-polarized light. 
time would have been a phenomenal $70 \mathrm{~m} / \mathrm{m}$.y. (Wise, this volume). An alternative explanation is that the interval actually spans a greater amount of time. If $C$. solitus persisted longer in the higher latitudes than in the tropics where Bukry's (1973a) zonation is grounded, then the subzone would encompass a greater amount of section.

Many of these questions could best be answered by further drilling in the vicinity of the Islas Orcadas piston cores discussed here. The section there is shallower and is far more calcareous in the Oligocene than the equivalent section at DSDP Site 511. In addition, exposure of progressively older sediments down the long northern slope of the Maurice Ewing Bank places the entire Tertiary section within sampling range of the hydraulic piston corer. The acquisition of such a section would be of great value to high-latitude biostratigraphy.

\section{ACKNOWLEDGMENTS}

The Islas Orcadas piston cores were taken during a cruise sponsored jointly by the U.S. National Science Foundation, the Argentine Naval Hydrographic Office, and the Argentine Antarctic Survey. Dr. Mostajo's participation in laboratory studies at Florida State University and subsequent investigations have been supported by NSF grants DPP 78-07183 and DPP 80-20382. We thank Dr. Andrew M. Gombos for re-examining his diatom data on the study material and providing us with his results. Ms. Mary Parker helped prepare the manuscript, which was typed by Ms. Pamela Rhymes.

\section{REFERENCES}

Bukry, D. 1973a. Low-latitude coccolith biostratigraphic zonation. In Edgar, N. T., Saunders, J. B., et al., Init. Repts. DSDP, 15: Washington (U.S. Govt. Printing Office), 685-703. 1973b. Coccolith stratigraphy, Eastern Equatorial Pacific, Leg 16, Deep Sea Drilling Project. In van Andel, Tj. H., Heath, G. R., et al., Init. Repts. DSDP, 16: Washington (U.S. Govt. Printing Office), 653-711.

Ciesielski, P. F., and Wise, S. W., 1977. Geologic history of the Maurice Ewing Bank of the Falkland Plateau (Southwest Atlantic sector of the Southern Ocean) based on piston and drill cores. Mar. Geol., 25:175-207.

Gombos, A. M., Jr., 1982. Three new and unusual genera of ebridians from the southwest Atlantic Ocean. J. Paleontol., 56:444-448.

Heck, S. E., van, 1979a. Bibliography and taxa of calcareous nannoplankton. Int. Nannoplankton Assoc. Newsl., 1:AB1-5, A1-12, B1-27.

, 1979b. Bibliography and taxa of calcareous nannoplankton. Int. Nannoplankton Assoc. Newsl., 1:ABVI, A13-28, B28-42.

1980a. Bibliography and taxa of calcareous nannoplankton. Int. Nannoplankton Assoc. Newsl., 2:5-34.

, 1980b. Bibliography and taxa of calcareous nannoplankton. Int. Nannoplankton Assoc. Newsl., 2:43-81.

, 1981a. Bibliography and taxa of calcareous nannoplankton. Int. Nannoplankton Assoc. Newsl, 3:4-41.

, 1981b. Bibliography and taxa of calcareous nannoplankton. Int. Nannoplankton Assoc. Newsl., 3:51-86.

1982. Bibliography and taxa of calcareous nannoplankton. Int. Nannoplankton Assoc. Newsl., 4:7-50.

Jones, S. C., Wise, S. W., Jr., DeFelice, D. R., Hattner, J. G., Mostajo, E. L., Gombos, A. M., and Weaver, F. M., 1979. Basal sediment ages of ARA Islas Orcadas cruise 16 piston cores. Antarc. J. U.S., 14:150-153.

Kaharoeddin, F. A., Graves, R. S., Bergen, J. A., Eggers, M. R., Harwood, D. M., Humphreys, C. L., Goldstein, E. H., Jones, S. C., and Watkins, D. K., 1982. ARA Islas Orcadas cruise 16-78, sediment descriptions. Fla. State Univ. Sed. Res. Lab. Contrib., 50: 172.

Loeblich Jr., A. R., and Tappan, H., 1966. Annotated index and bibliography of the calcareous nannoplankton. Phycologia, 5:81-216.
, 1968. Annotated index and bibliography of the calcareous nannoplankton III. J. Paleontol., 42:584-598.

, 1969. Annotated index and bibliography of the calcareous nannoplankton III. J. Paleontol., 43:568-588.

,1970a. Annotated index and bibliography of the calcareous nannoplankton IV. J. Paleontol., 44:558-574.

, 1970b. Annotated index and bibliography of the calcareous nannoplankton V. Phycologia, 9:157-174.

, 1971. Annotated index and bibliography of the calcareous nannoplankton VI. Phycologia, 10:315-339.

$\rightarrow$ 1973. Annotated index and bibliography of the calcareous nannoplankton VII. J. Paleontol., 47:715-759.

Wise, S. W., Jr., Jones, S. C., Ciesielski, P. F., Georgi, D. T., Woodroffe, D. S., and Jacobs, S. S., 1978. Islas Orcadas cruise 16. Antarct. J. U.S., 13:92-94.

\section{APPENDIX \\ Calcareous Nannofossil Species Considered in This Report, Listed in Alphabetical Order of Species Epithets}

The bibliographic references for these species are provided in Wise (this volume), Loeblich and Tappan (1966, 1968, 1969, 1970a, b, 1971, 1973) and Heck (1979a, b, 1980a, b, 1981a, b, 1982).

Discoaster adamanteus Bramlette and Wilcoxon, 1967

Chiasmolithus altus Bukry and Percival, 1971

Discoaster barbadiensis Tan Sin Hok, 1927

Discoaster bifax Bukry, 1971

Zygrhablithus bijugatus (Deflandre) Deflandre, 1959

Discoaster binodosus Martini, 1958

Reticulofenestra bisecta bisecta (Hay, Mohler, and Wade) Roth, 1970

Reticulofenestra bisecta filewiczii Wise and Wiegand in Wise, this volume

Helicosphaera carteri (Wallich) Kamptner, 1954

Reticulofenestra daviesii (Haq) Haq, 1971

Discoaster deflandrei Bramlette and Riedel, 1954

Ellipsolithus distichus (Bramlette and Sullivan) Sullivan, 1964

Discoaster distinctus Martini, 1958

Neococcolithes dubius (Deflandre) Black, 1967

Chiasmolithus expansus (Bramlette and Sullivan) Gartner, 1970

Clausicoccus fenestratus (Deflandre and Fert) Prins, 1979

Cyclicargolithus floridanus (Roth and Hay) Bukry, 1971

Coccolithus formosus (Kamptner) Wise, 1973

Sphenolithus furcatolithoides Locker, 1967

Chiasmolithus grandis (Bramlette and Riedel) Gartner, 1970

Reticulofenestra hesslandii (Haq) Roth, 1970

Reticulofenestra sp. cf. R. hesslandii (small) (Haq) Roth, 1970

Reticulofenestra hillae Bukry and Percival, 1971

Markalius inversus (Deflandre) Bramlette and Martini, 1964

Calcidiscus leptoporus (Murray and Blackman) Loeblich and Tappan, 1978

Sphenolithus moriformis (Brönnimann and Stradner) Bramlette and Wilcoxon, 1967

Cyclicargolithus sp. cf. C. pseudogammation (Bouche) Bukry, 1973

Chiasmolithus oamaruensis (Deflandre) Hay, Molhler and Wade, 1966 Reticulofenestra oamaruensis (Deflandre) Stradner and Edwards, 1968

Reticulofenestra onusta (Perch-Nielsen) Wise, n. comb.

Pontosphaera pectinata (Bramlette and Sullivan) Proto Decima, Roth, and Todesco, 1975

Coccolithus pelagicus (Wallich) Schiller, 1930

Pontosphaera plana (Bramlette and Sullivan) Haq, 1971

Pontosphaera pulcheroides (Sullivan) Romein, 1979

Nannotetrina quadrata (Bramlette and Sullivan) Bukry, 1973

Isthmolithus recurvus Deflandre in Deflandre and Fert, 1954

Discoaster saipanensis Bramlette and Riedel, 1954

Reticulofenestra samodurovi (Hay, Mohler, and Wade) Bukry and Percival, 1971

Chiasmolithus solitus var. inversus Wise and Weigand in Wise, this volume

Blackites spinosus (Deflandre and Fert) Hay and Towe, 1962

Coccolithus staurion Bramlette and Sullivan, 1961

Reticulofenestra umbilica (Levin) Martini and Ritzkowski, 1968 

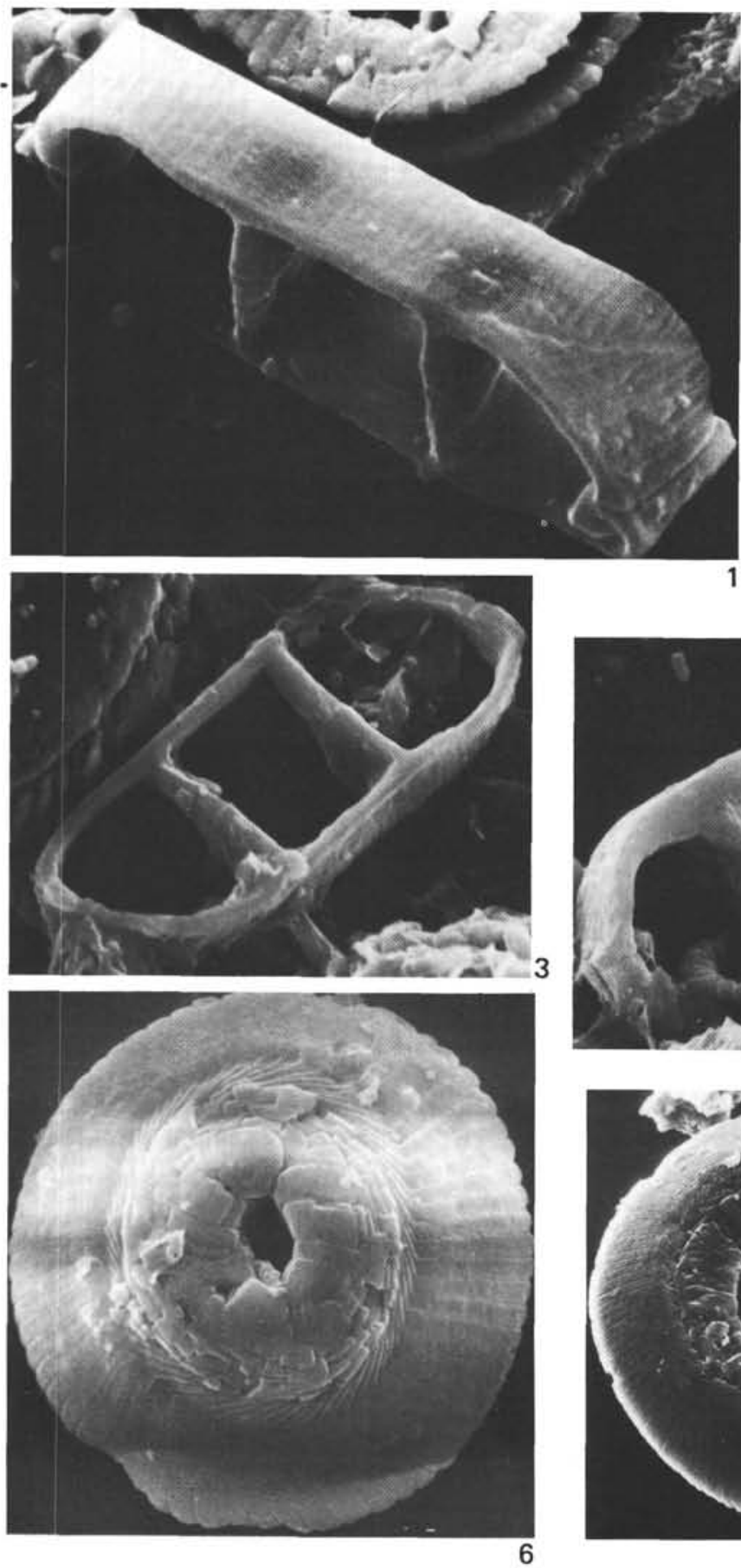

6
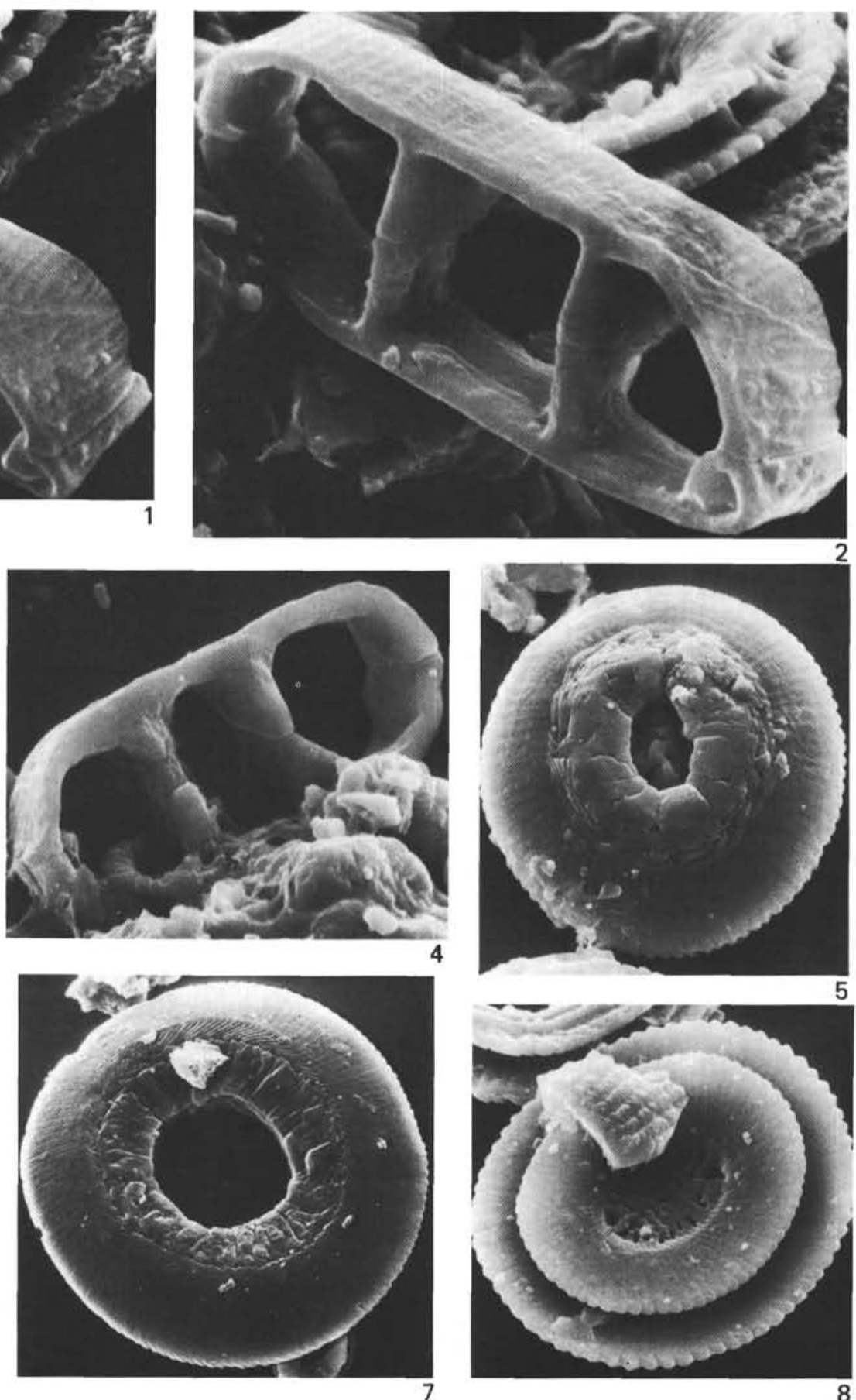

5

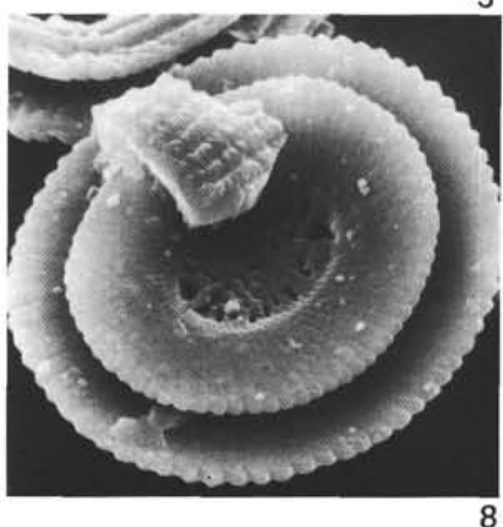

Plate 1. Lower Oligocene calcareous nannofossils, SEM. 1-4. Isthmolithus recurvus Deflandre (1-2) $\times 10,500$, Sample IO $16-45,20 \mathrm{~cm}$, (3) $\times 7500$, Sample IO 16-45, $60 \mathrm{~cm}$, (4) $\times 8000$, Sample IO 16-45, $20 \mathrm{~cm} .5-6,8$. Reticulofenestra bisecta filewiczii Wise and Wiegand, Sample IO $16-45,40 \mathrm{~cm},(5-6)(5$, distal views, $\times 4400 ; 6, \times 7000)$, (8) proximal view, $\times 5500$. 7. Reticulofenestra umbilica (Levin) Martini and Ritzkowski; distal view, $\times 3200$, Sample IO $16-45,40 \mathrm{~cm}$. 

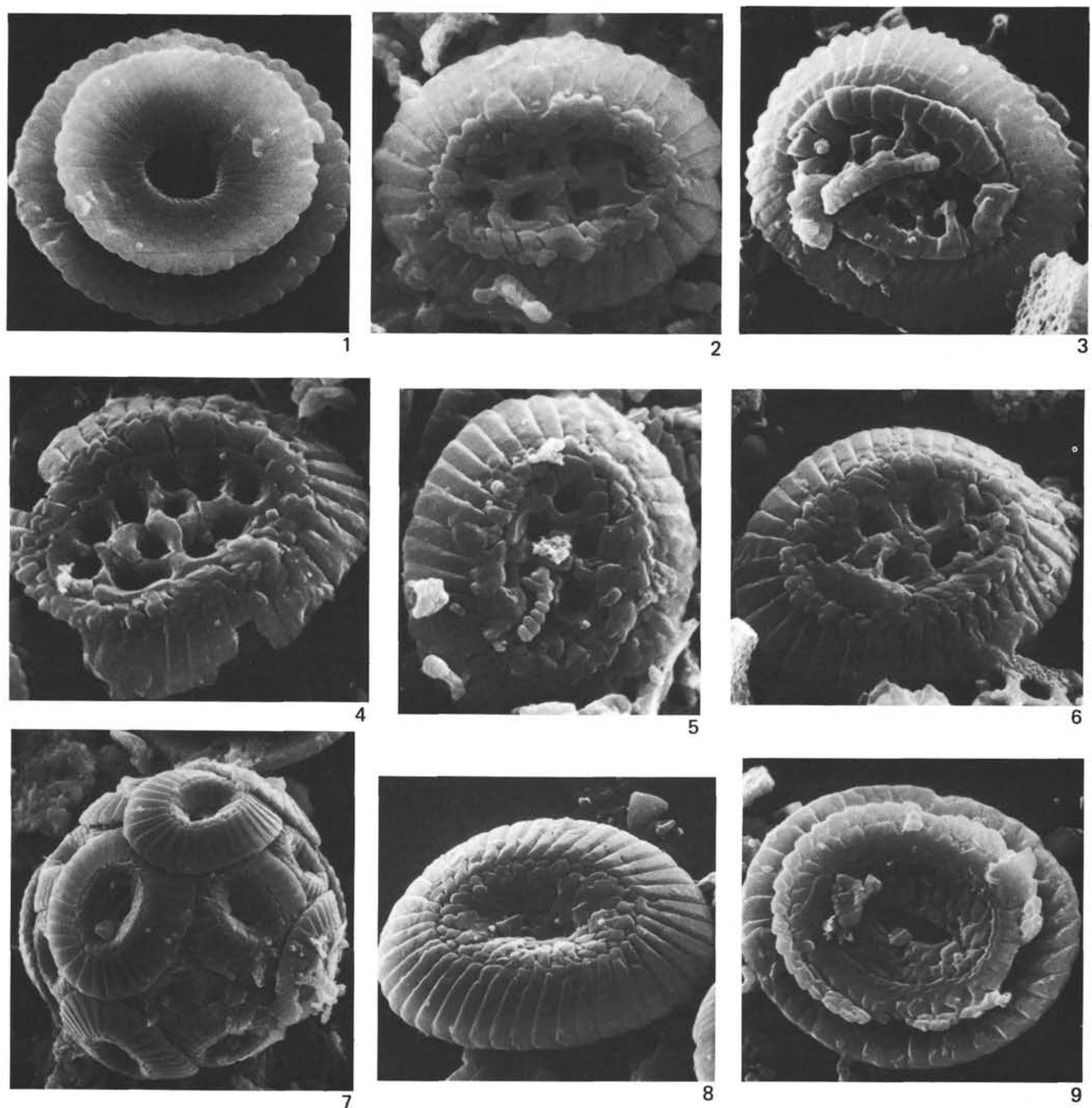

Plate 2. Lower Oligocene calcareous nannofossils, SEM. 1. Cyclicargolithus floridanus (Roth and Hay) Bukry; proximal view, $\times 9000$, Sample IO 16-45, $40 \mathrm{~cm}$. 2-6. Clausicoccus fenestratus (Deflandre and Fert) Prins, distal views, (2) $\times 8000$, Sample IO 16-45, 20 cm, (3) $\times 11,000$, Sample IO 16-45, $40 \mathrm{~cm},(4) \times 9500$, Sample IO $16-45,20 \mathrm{~cm},(5-6)$ Sample IO $16-45,60 \mathrm{~cm}(5, \times 9000 ; 6, \times 10,000)$. 7-9. Coccolithus pelagicus (Wallich) Schiller, (7) coccosphere, $\times 4100$, Sample IO 45-16, $20 \mathrm{~cm}$, (8) distal view, $\times 5000$, Sample IO 16-45, 40 cm, (9) proximal view, $\times 7000$, Sample IO $16-45,60 \mathrm{~cm}$. 

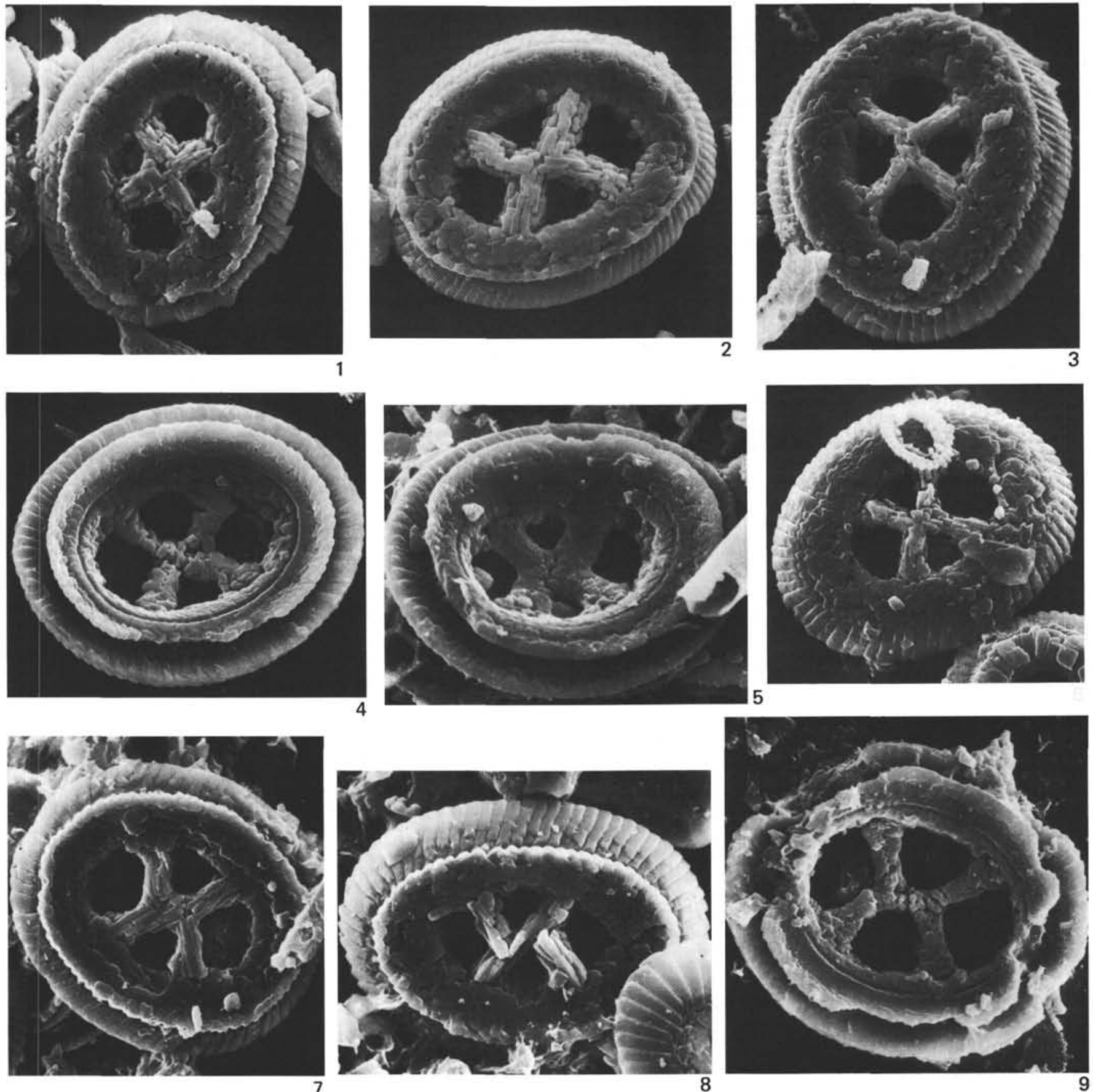

Plate 3. Lower Oligocene and middle Eocene calcareous nannofossils, SEM. 1-6. Chiasmolithus altus Bukry and Percival, Lower Oligocene, (13) distal views $(1, \times 4200$, Sample IO $16-45,20 \mathrm{~cm} ; 2, \times 4100$, Sample IO 16-45, $40 \mathrm{~cm} ; 3, \times 4400$, Sample IO 16-45, 40 cm), (4-5) proximal views $(4, \times 4800$, Sample IO $16-45,40 \mathrm{~cm} ; 5, \times 5500$, IO $16-45,60 \mathrm{~cm},(6)$ distal view, $\times 5500$, Sample IO $16-45,20 \mathrm{~cm}$. 7-8. Chiasmolithus solitus (Bramlette and Sullivan) Locker, middle Eocene, distal view, Sample IO 16-44, $40 \mathrm{~cm},(7) \times 4100$, (8) $\times 5500$. 9. Chiasmolithus expansus (Bramlette and Sullivan) Gartner, middle Eocene, proximal view, $\times 4100$, Sample IO $16-45,40 \mathrm{~cm}$. 

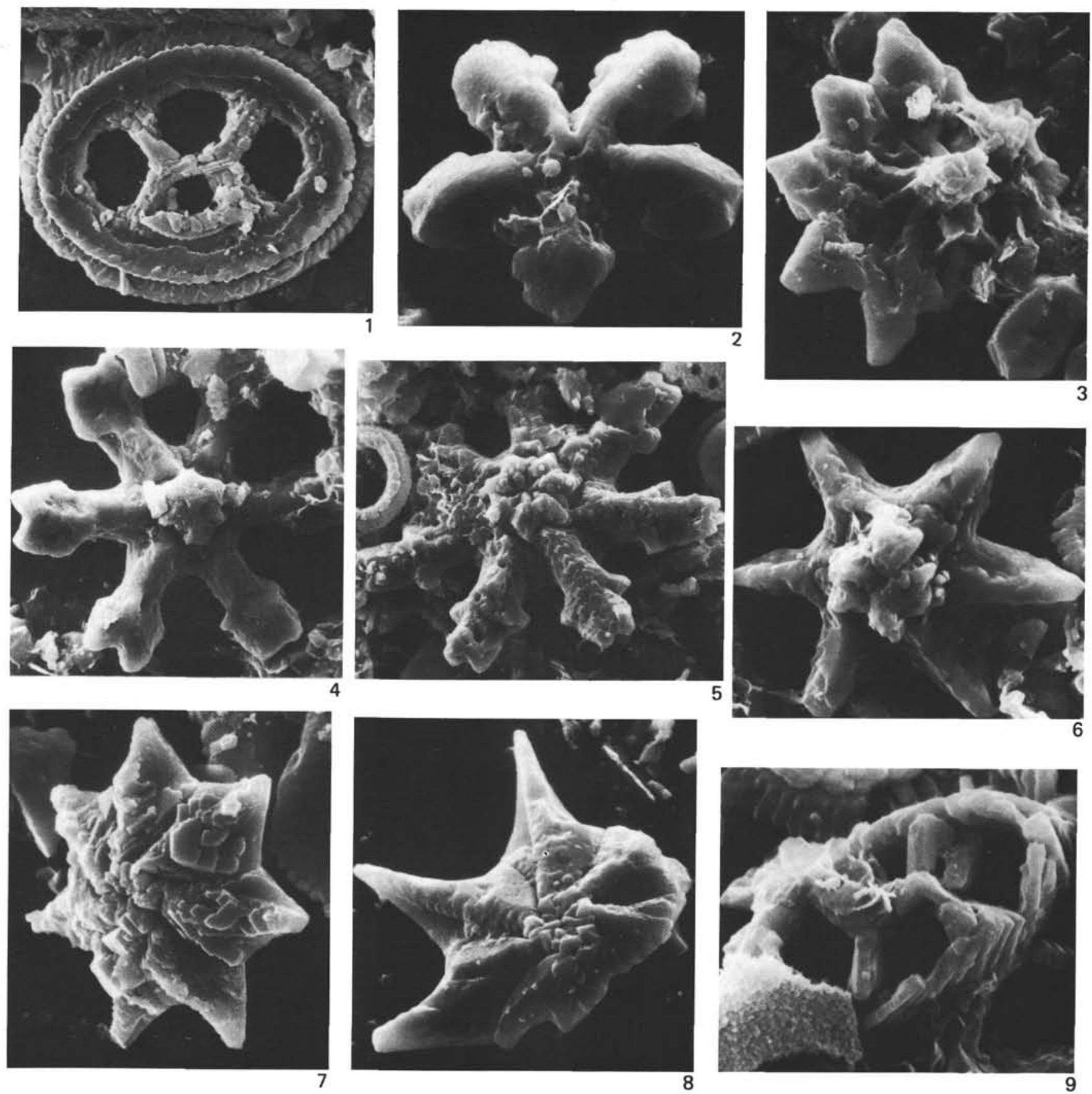

Plate 4. Middle Eocene calcareous nannofossils, SEM, Sample IO $16-44,40 \mathrm{~cm}$. 1. Chiasmolithus expansus (Bramlette and Sullivan) Gartner, distal view, $\times 3500$. 2. Discoaster sp., $\times 7600$. 3. Discoaster barbadiensis Tan Sin Hok, $\times 6500$. 4. Discoaster distinctus Martini, $\times 4300$. 5. Discoaster binodosus Martini, $\times 3300$. 6. Discoaster sp., $\times 7000$. 7-8. Discoaster saipanensis Bramlette and Riedel, (7) $\times 6500$, (8) $\times 6200$. 9. Neococcolithes dubius (Deflandre) Black, distal view, $\times 10,000$. 